DEMOGRAPHIC RESEARCH

VOLUME 36, ARTICLE 52, PAGES 1601-1636 PUBLISHED 16 MAY 2017

http://www.demographic-research.org/Volumes/Vol36/52/

DOI: 10.4054/DemRes.2017.36.52

Research Article

The relationship between women's paid employment and women's stated son preference in India

Julia Behrman

Sara Duvisac

(C) 2017 Julia Behrman \& Sara Duvisac.

This open-access work is published under the terms of the Creative Commons Attribution NonCommercial License 2.0 Germany, which permits use, reproduction \& distribution in any medium for non-commercial purposes, provided the original author(s) and source are given credit.

See http:// creativecommons.org/licenses/by-nc/2.0/de/ 


\section{Contents}

1 Introduction 1602

2 Literature 1604

2.1 Sociocultural and economic drivers of son preference 1604

2.2 Women's employment in India 1605

2.3 Why might women's paid employment be associated with changes 1606 in women's stated son preference?

3 Empirical strategy 1608

3.1 Data and sample 1608

3.2 Method 1609

3.3 Paid employment variables 1610

$\begin{array}{lll}3.4 & \text { Controls } & 1611\end{array}$

$\begin{array}{lll}3.5 & \text { Stated son preference outcome } & 1612\end{array}$

$4 \quad$ Results 1613

4.1 Descriptive overview of women's participation in paid employment 1613

4.2 Logistic regression analysis of the relationship between women's 1614 paid employment and women's stated son preference using an aggregated measure of paid employment

4.3 Logistic regression analysis of the relationship between women's 1619 paid employment and women's stated son preference disaggregating by sector of employment

$\begin{array}{lll}4.4 & \text { Supplementary analyses } & 1622\end{array}$

5 Discussion 1623

6 Acknowledgments 1626

$\begin{array}{ll}\text { References } & 1627\end{array}$

$\begin{array}{ll}\text { Appendix } & 1632\end{array}$ 


\title{
The relationship between women's paid employment and women's stated son preference in India
}

\author{
Julia Behrman ${ }^{1}$ \\ Sara Duvisac $^{2}$
}

\begin{abstract}
OBJECTIVE

We explore whether women's paid employment is associated with reductions in women's stated son preference in India and whether these results vary by employment sector (agriculture, manufacturing, services, professional-technical) and skill level (education and literacy).
\end{abstract}

\section{METHODS}

We conduct a logistic regression analysis of the relationship between women's paid employment and women's stated son preference among a sample of never-pregnant Indian women. We use the 2005 India National Family Health Survey (NFHS).

\section{RESULTS}

Women's paid employment in the service and manufacturing sectors is associated with significant reductions in the stated son preference of low-skilled women (i.e., low education and literacy). However, this negative association goes away for women at higher skill levels. In fact, paid employment in manufacturing is associated with significantly higher stated son preference among university-educated women. However, women's paid employment in agriculture and the professional-technical sectors is not significantly associated with women's stated son preference. Finally, the association between women's paid employment and stated son preference is significantly larger for women living in north India than for women living in south and east India.

\section{CONCLUSIONS}

We hypothesize that significant negative associations between women's paid employment and women's stated son preference occur only in cases where paid employment changes the economic status of women within the family.

\section{CONTRIBUTION}

Our analysis demonstrates that there are important linkages between women's paid

${ }^{1}$ Department of Sociology, New York University, USA. E-Mail: jab965@nyu.edu.

${ }^{2}$ Department of Sociology, New York University, USA. 
employment and stated son preference, and draws attention to how the context of employment (e.g., sector and skill level) is differentially associated with demographic outcomes.

\section{Introduction}

Son preference has prevailed in India for centuries and continues to shape the demographic behaviors and well-being of Indian women throughout the life course. ${ }^{3}$ Son preference manifests itself in many forms in contemporary India, including lower nutritional and educational investment in female children, higher mortality rates for female infants, and sex ratios that are skewed towards males (Arnold, Choe, and Roy 1998; Jha et al. 2011; Sen and Sengupta 1983). The prevalence of son preference has high social and economic costs, including the elevated morbidity and mortality of women and girls, a distorted marriage market, and loss of potential human capital. Given all of this, considerable research and policy attention has focused on identifying factors associated with reductions in son preference. For example, research indicates that education, urbanization, and media access are all negatively associated with women's stated son preference (Bharati et al. 2011; Pande and Astone 2007; Pande and Malhotra 2006).

There has been comparatively less research and policy attention on the relationship between women's employment and son preference. ${ }^{4}$ However, existing literature indicates a plausible relationship between women's paid employment and changes in son preference. For example, women's employment might be associated with reductions in son preference because earning income strengthens women's economic position in the family unit and reduces perceptions that women are financially burdensome (Das Gupta et al. 2003). Furthermore, paid employment may also expose women to new gender and family norms and increase women's social autonomy (Chakravarty and Chakravarty 2015; Neetha 2004). In support of this perspective,

\footnotetext{
3 'Son preference' refers to families' preference for having male children over female children and the differential resources families invest in male children as compared to female children.

${ }^{4}$ Throughout the paper we focus on paid employment rather than unpaid work in the household because household work is not remunerated or acknowledged as important for household income security by the family unit; thus we would not expect household work to improve the economic status or personal autonomy of women. Nonetheless, women's unpaid household and care work is critical to the sustainability of households in India (Ferrant et al. 2014). In India women perform 10 times more unpaid care and household work than men, a figure that is considerably higher than the global average (Woetzel et al. 2015). While we do not want to understate the importance of women's unpaid work, we argue there is an important rationale for considering the relationship between women's paid employment and women's stated son preference.
} 
several cross-sectional studies find that women's employment is associated with significantly higher survival rates for women and girls (Kishor 1993; Murthi, Guio, and Drèze 1995; Rosenzweig and Schultz 1982). ${ }^{5}$

However, existing literature on women's employment and son preference does not consider heterogeneity in women's employment experiences. Growth in women's employment in India in the past two decades has been uneven and employment opportunities for women are often insecure, informal, or low-wage (Chaudhary and Verick 2014; Mitra 2005). If paid employment opportunities do not change women's economic or social status within the family there may be no association between women's paid employment and stated son preference (Das Gupta et al. 2003). Paid employment may even be associated with increases in stated son preference by providing lower status/lower caste women with the resources to emulate the son preferences of higher status/higher caste families (Basu 1999).

We conduct a multivariate analysis of the relationship between women's paid employment and women's stated son preference using data from the 2005 round of the India National Family Health Survey (NFHS). Our analysis extends previous studies on the topic by disaggregating women's employment into sectors (agricultural, manufacturing, services, professional-technical) and exploring how results vary depending on skill (education and literacy). This is an important distinction, given the substantial differences in wages and working conditions across employment sectors in India. Furthermore, much of the existing literature focuses on how geography and kinship influence the relationship between women's employment and sex ratios (Dyson and Moore 1983; Kishor 1993), whereas our study explores how women's employment is associated with stated son preference net of kinship, geography, or socioeconomic status. Finally, we focus on stated son preference outcomes as opposed to sex ratios or child survival rates (the focus of existing literature). While the latter set of outcomes provides valuable information about how families invest resources in children (Rosenzweig and Schultz 1982), stated son preference outcomes provide valuable information about intra-familial gender norms that may not be captured by resource allocation measures.

\footnotetext{
${ }^{5}$ Female survival rates are used as indicators of son preference. Past literature has also extensively explored the relationship between women's employment and fertility (Becker 1981; Kasarda 1971; Schockaert 2005).
} 


\section{Literature}

\subsection{Sociocultural and economic drivers of son preference}

The ongoing prevalence of son preference in India is driven by a combination of interrelated and mutually reinforcing sociocultural and economic factors. Traditional kinship and inheritance systems play an important role in shaping women's economic position in the family (Das Gupta et al. 2003; Dyson and Moore 1983). Patrilocal kinship and patrilineal inheritance system patterns prevail throughout India, and are especially strong in northern and northwestern India (Basu 1999; Dyson and Moore 1983). In patrilocal kinship systems, women are absorbed into their husband's lineage upon marriage and reside with their husband's family (Das Gupta et al. 2003). Likewise, in patrilineal inheritance systems all familial inheritance is transferred to male heirs (ibid). Patrilocal-patrilineal norms reinforce preference for sons because families do not expect to benefit from investing in daughters who will leave the natal home upon marriage (Das Gupta et al. 2003; Robitaille 2013), while sons are expected to provide financial assistance to aging parents and to pass family property on to the next generation (Das Gupta et al. 2003). Empirical evidence suggests that patrilocal kinship systems are associated with lower rates of female child survival (Kishor 1993; Dyson and Moore 1983). Despite legal protections for female inheritance in the last few decades, restrictions on women's ability to inherit family property continue in many regions of India (Agarwal 1988).

The practice of dowry - payment from the bride's family to the husband's family upon marriage - also contributes to the low economic status of women. Daughters are often perceived to be an economic burden on their families because of the high costs of dowry (Diamond-Smith, Luke, and McGarvey 2008). Although the dowry system is illegal, dowry continues to be widely practiced throughout India (Srinivasan and Lee 2004). It is also practiced in regions where it has not been present historically. For example, in most of southern India upper caste families used to practice sridhananam, the gifting of part of the family property to the bride, rather than dowry (Mukund 1999). In recent history, sridhananam has been replaced with the direct payment of cash or goods from the bride's family to the bridegroom's family (ibid.). Dowry has also come to be expected by groups that historically did not practice it. For example, in the past dowry was almost exclusively a practice of higher caste families, whereas in contemporary India it is widely practiced by all castes (Basu 1999).

Nonetheless, there are important regional differences in inheritance and kinship in India. Patrilocality is not as strong in southern India, where in some areas matrilineal kinship patterns persisted through the $18^{\text {th }}$ and $19^{\text {th }}$ centuries (Das Gupta et al. 2003; Dyson and Moore 1983; Mukund 1999). As a result, women in southern India have 
historically had more frequent contact with their natal families following marriage and more secure property rights from natal families (Bhat, Mari, and Zavier 2003; Dyson and Moore 1983; Mukund 1999). On the other hand, in northern and northwestern India women's inheritance of land has historically been restricted and women are often entirely dependent on their husband's family for economic stability (Das Gupta et al. 2003).

Regional differences in investment in women's education have also contributed to regional differences in the status of women (Bharati et al. 2011). Some southern states most notably Kerala - invested heavily in both men's and women's education before and after India gained independence from the United Kingdom in 1947 (Mitra and Singh 2006; Saradamoni 1994). As a result, women's literacy and educational attainment is much higher in southern India than in northern India, where no comparable educational reforms have taken place (Saradamoni 1994). Arguably, regional differences in inheritance, kinship system, and educational investment partially account for the disproportionately higher skewed sex ratios in northern and northwestern states of India compared to southern states (Sudha and Rajan 1999).

\subsection{Women's employment in India}

Historically, women in India participated in the labor force at low rates due to social norms restricting female mobility, lower levels of education relative to men, and lack of formal sector opportunities (Chaudhary and Verick 2014). Women's employment had begun to increase by the end of the $20^{\text {th }}$ century as economic growth opened new opportunities for women, particularly in the service and manufacturing sectors. Between 1994 and 2010 women's employment increased by 8.7 million women (Chaudhary and Verick 2014). Women's labor force participation in India reached a high of 37\% in 2005 (World Bank 2016). World Bank (2014) estimates suggest that $62 \%$ of employed women in India work in the agricultural sector, $15 \%$ in the manufacturing sector, and $13 \%$ in the service sector. ${ }^{6}$

Despite these increases in women's employment, India continues to have low female labor force participation compared to other low- and middle-income countries (World Bank 2016). Furthermore, growth in Indian women's employment opportunities has been concentrated in nonpermanent, low-paying, informal positions where women do not have fixed contracts (Mitra 2006). For example, women's employment opportunities are disproportionately in low-skilled positions in agriculture, sales and elementary services, and handicraft manufacturing (Chaudhary and Verick 2014). Wage

\footnotetext{
${ }^{6}$ The World Bank estimates do not separate professional-technical jobs from service jobs.
} 
discrimination against women is also common because women are viewed as a source of cheap labor compared to men (Chaudhary and Verick 2014; Mitra 2005).

In addition to difficult working conditions, employment often places a double burden on Indian women, who are expected to balance family care and work responsibilities. Many married women seek flexible employment opportunities to have time for household and childcare duties (Mitra 2006). However, flexible positions are typically less secure and lower-waged. Given the constraints on married women's time, some sectors are limited to women who are unmarried. For example, service sector jobs are often restricted to single women because the late hours associated with these occupations are thought to be incompatible with the duties of wives (Singh and Pandey 2005).

Many Indian women enter the labor force as a survival strategy to alleviate household economic stress (Abraham 2009; Chaudhary and Verick 2014; Noponen 1991). Studies indicate that there is a U-shaped relation between class and employment for single women in India, where middle class women work at lower rates than upper class and lower class women (Panda 2003; Rustagi 2010). The explanation behind the ' $U$ ' shape is that lower class women work in poorly paid and strenuous positions out of necessity, middle class women opt out of work if they can afford it, and upper class women chose to engage in higher-skilled, more prestigious positions. These class-based disparities in women's employment status suggest that women from diverse classes enter the workforce for very different reasons. It follows that the association between women's employment and stated son preference may be dependent on type of employment and socioeconomic background.

\subsection{Why might women's paid employment be associated with changes in women's stated son preference?}

There are several reasons why paid employment might be associated with reductions in son preference. Earning an income might improve the economic status of women in the family by changing women's perception that daughters will be economically burdensome. This may particularly be the case if working women become important financial providers for their natal family. For example, evidence suggests that young working women in urban areas send a considerable portion of their income back to their parents (Sundari 2005). Women who play an important role in the financial security of their natal family may come to view daughters as sources of financial security rather than an economic burden.

Furthermore, paid employment might increase women's social autonomy and expose women to new gender norms. This may be particularly the case for young rural 
women who migrate to urban areas for work and gain social independence from their natal communities in the process (Chakravarty and Chakravarty 2015). Employment exposes young female migrants to new social networks and social norms (Neetha 2004). Women's financial independence may also contribute to changes in marriage norms among migrant populations. For example, employment at call centers was associated with significant delays in age at first marriage among migrant female populations in India (Singh and Pandey 2005). Likewise, community-level increases in female employment in the business process outsourcing industry had a significant negative effect on the probability of young women starting marriage and childbearing among rural women in India (Jensen 2012). Changes in women's own social autonomy may lead to changes in women's ideas about the social value of daughters.

In fact, several cross-sectional studies examine the relationship between women's employment and indicators of son preference, including female survival rates and sex ratios in India (Kishor 1993; Murthi, Guio, and Drèze 1995; Rosenzweig and Schultz 1982). These studies indicate that women's employment is associated with higher survival rates for women and girls (Kishor 1993; Murthi, Guio, and Drèze 1995; Rosenzweig and Schultz 1982).

However, not all paid employment opportunities lead to increased financial autonomy for women because most female employment in India is low-wage, insecure, seasonal, or part-time (Chaudhary and Verick 2014). Women employed in insecure, part-time, or low-wage positions may not be able to make sustained financial contributions to their family. Furthermore, women's employment may not be sufficient to change son preference given the prevalence of dowry, poor enforcement of property rights for women, and patrilocal kinship systems (Das Gupta et al. 2003). The dual pressure on women to earn income and perform unpaid household labor might even contribute to the marginalization of women in the homestead.

Furthermore, the high opportunity costs of women's employment may induce women to make a tradeoff between child quantity and child quality (Becker 1981). If employed women have fewer total children, and if boys are considered higher quality than girls, then this may contribute to sex ratios skewed towards boys. Women's employment may be associated with increases in son preference by providing lower status/lower caste women with the resources to emulate the preferences and cultural practices of higher status/higher caste families (Basu 1999; Sudha and Rajan 1999). 


\section{Empirical strategy}

\subsection{Data and sample}

We use data from the 2005 round of the NFHS (NFHS-3). The NFHS is a nationally representative, cross-sectional, standardized household survey, collected by the International Institute for Population Sciences in collaboration with IFC International and the Government of India. The NFHS includes detailed information on the fertility preferences and behaviors of all women aged 15-49 in sampled households. The NFHS also collects data on women's participation in paid employment over the previous 12 months, including information about employment sector, employment type (full-time, seasonal, occasional), and compensation for employment (unpaid, compensation in cash, and compensation in kind).

We limit our analytical sample to women who have never been pregnant (e.g., we exclude women who have given birth and women who have had an abortion, miscarriage, or stillbirth). We also exclude women who report desiring no children $(n=754)$. Our analytic sample of never-pregnant women is on average younger, less likely to be married, better-educated, and more exposed to media than the NFHS sample of women who have been pregnant (Table 1). Although our sample of never pregnant women is not representative of Indian women there are several advantages to focusing on this subpopulation. Restricting our sample to women who have never been pregnant helps to address concerns about reverse causation between women's employment and women's stated son preference. For example, women who have children may leave the labor market to take care of them, thus making it difficult to tell if women's employment leads to changes in son preference or if son preference leads to changes in women's employment status. Focusing on women who have never been pregnant also assuages concerns that women's responses to questions about son preference are driven by ex-post facto rationalization based on the sex of their current children. 
Table 1: Variables used in the analysis and comparison of women who have never been pregnant with women who have been pregnant

\begin{tabular}{|c|c|c|c|c|}
\hline & \multicolumn{2}{|c|}{$\begin{array}{l}\text { Analytical sample (women who } \\
\text { have never been pregnant) }\end{array}$} & \multicolumn{2}{|c|}{$\begin{array}{l}\text { Comparison sample (women } \\
\text { who have been pregnant) }\end{array}$} \\
\hline & Mean & Std. Dev. & Mean & Std. Dev. \\
\hline Stated son preference $(0-1)$ & 0.13 & 0.33 & 0.26 & 0.44 \\
\hline Paid employment last 12 mo. (0-1) & 0.17 & 0.37 & 0.20 & 0.40 \\
\hline Paid employment in agriculture in last $12 \mathrm{mo} .(0-1)$ & 0.03 & 0.17 & 0.08 & 0.26 \\
\hline Paid employment in manufacturing in last $12 \mathrm{mo} .(0-1)$ & 0.06 & 0.24 & 0.06 & 0.23 \\
\hline Paid employment in services in last $12 \mathrm{mo} .(0-1)$ & 0.03 & 0.16 & 0.04 & 0.20 \\
\hline Paid employment in professional-technical in last $12 \mathrm{mo} .(0-1)$ & 0.05 & 0.21 & 0.02 & 0.16 \\
\hline No school (0-1) & 0.18 & 0.38 & 0.49 & 0.49 \\
\hline Primary school (0-1) & 0.12 & 0.33 & 0.15 & 0.36 \\
\hline Secondary school (0-1) & 0.57 & 0.50 & 0.30 & 0.46 \\
\hline Tertiary school (0-1) & 0.13 & 0.33 & 0.05 & 0.23 \\
\hline Years of schooling & 7.68 & 4.72 & 4.08 & 4.81 \\
\hline Literate (0-1) & 0.74 & 0.44 & 0.41 & 0.49 \\
\hline Wealth (1-5) & 3.34 & 1.38 & 3.04 & 1.41 \\
\hline Regular access to media $(0-1)$ & 0.75 & 0.43 & 0.59 & 0.49 \\
\hline Urban residence $(0-1)$ & 0.38 & 0.49 & 0.31 & 0.46 \\
\hline Ever married (0-1) & 0.26 & 0.44 & 1.00 & 0.02 \\
\hline Age & 19.67 & 5.26 & 32.69 & 8.28 \\
\hline Hindu $(0-1)$ & 0.81 & 0.39 & 0.81 & 0.39 \\
\hline Muslim (0-1) & 0.13 & 0.33 & 0.13 & 0.34 \\
\hline Sikh $(0-1)$ & 0.02 & 0.13 & 0.02 & 0.13 \\
\hline Christian (0-1) & 0.03 & 0.16 & 0.02 & 0.15 \\
\hline Other religion (0-1) & 0.02 & 0.13 & 0.01 & 0.12 \\
\hline Scheduled caste $(0-1)$ & 0.18 & 0.38 & 0.19 & 0.40 \\
\hline Scheduled tribe $(0-1)$ & 0.08 & 0.27 & 0.08 & 0.28 \\
\hline $\mathrm{N}$ & 34,450 & & 81,760 & \\
\hline
\end{tabular}

Weighted using sampling weights provided by NFHS.

\subsection{Method}

We conduct a logistic regression analysis of the relationship between women's paid employment and women's stated son preference. To understand if the relationship between women's paid employment and women's stated son preference varies by skill level we include interactions between paid employment and two measures of skill: women's education level and women's literacy.

The largest limitation of our analysis is that women who engage in paid employment may be different from women who do not engage in paid employment on both observed and unobserved characteristics. Selection into employment is a concern 
because of the 'U-shaped' relationship between women's employment and class, where women's employment is highest among the poorest and wealthiest women (Panda 2003; Rustagi 2010; Singh and Pandey 2005). We account for selection into employment by controlling for a wide range of socioeconomic and sociocultural controls (described below). However, there are undoubtedly unobserved characteristics such as ability or ambition that we cannot control for and that influence both women's participation in paid employment and women's stated son preferences.

\subsection{Paid employment variables}

Employment takes many different forms in India including seasonal, part-time, fulltime, paid in cash, paid in kind, formal, informal etc. The NFHS includes a number of different questions about women's employment conducted in the last 12 months including: whether the respondent worked at all in the last 12 months; whether the respondent was compensated for work in the last 12 months in cash, in-kind, or both in cash and in-kind; whether the respondent worked full-time (all year), occasionally, or seasonally in the last 12 months; and the type of work the respondent conducted in the last 12 months (including detailed occupational titles).

For our analysis, paid employment is defined as full-time (all year) paid (cash) employment for at least the last 12 months. We exclude uncompensated employment and employment compensated in kind because we hypothesize that cash income is important for changing the economic status of women. ${ }^{7}$ Likewise, we exclude occasional and seasonal employment to ensure that women had a stable position over a long enough period so that we could plausibly see employment effects.

We create an aggregated measure of paid employment by creating a dichotomous indicator of whether the respondent engaged in full-time paid employment in the last 12 months (the reference category is women who did not work full-time for cash in the last 12 months). We also create four dichotomous indicator variables for 1) full-time paid employment in the agriculture sector in the last 12 months (e.g., forestry, mining, fishing, farming, plantation workers, cultivators, and miners); 2) full-time paid employment in the manufacturing sector in the last 12 months (e.g., petty production workers such as glass formers, paper product makers, and factory workers); 3) full-time paid employment in the service sector in the last 12 months (e.g., sales workers, maids, cooks, and those working in insurance and real estate firms); and 4) full-time paid employment in the professional-technical sector in the last 12 months (e.g., scientists, medical personal, accountants, supervisors, and clerical personnel). For each of these

${ }^{7}$ In supplementary analysis (not shown) we distinguish between employment compensated in cash, employment compensated in kind, and uncompensated employment; only the first is statistically significant. 
variables the reference category is women who did not engage in full-time paid employment in the last 12 months. We characterize employment title by sector, largely following the categorization of the Indian Census and the World Bank but adding an additional category of 'professional-technical.' For detailed information about the types of occupation found within each sector, see Table A-1.

The greatest limitation of our employment measures is that we are unable to ascertain the relationship between employment duration and stated son preference. Employment duration is of interest because there may be stronger effects among women who have been working for a longer period. Furthermore, we assume that the woman has been engaged in the same type of job for the last 12 months (e.g., same sector, same compensation etc.). This is a relatively safe assumption, since switching between sectors over a relatively short time period is unlikely, given the differences in skill level needed to change sector. All employment variables are self-reported and thus are also subject to reporting bias.

\subsection{Controls}

Our controls for respondent skill level are schooling and literacy. Schooling is captured by dichotomous indicators of highest level of school attained (none, primary, secondary, tertiary); results are robust to using a continuous measure of schooling instead (Table A-2). Literacy is captured by a dichotomous indicator of whether the respondent can read a short sentence provided by the NFHS enumerator.

All models also include controls for other dimensions of socioeconomic status: wealth, urbanization, and media exposure. Wealth is measured using the NFHSgenerated household wealth index, which provides a 1-5 scale of the household wealth quintile in comparison to other households in the sample. The index is created by NFHS using household assets and homestead characteristics. Urbanization is captured with a dichotomous indicator variable for whether the respondent lives in an urban area. Frequent media exposure is measured by a dichotomous indicator for whether the respondent watches television or listens to the radio at least once a week.

We also control for life course and sociocultural controls: age; whether the respondent has been married; religion of respondent (Hindu, Christian, Muslim, Sikh, Other); and whether the respondent is a member of a scheduled caste or tribe. All models include state-fixed effects to account for unobserved factors at the state level. Robust standard errors are clustered at the primary sampling unit level in all models. 


\subsection{Stated son preference outcome}

The main outcome of our analysis is women's stated son preference. We follow the convention of other scholars and create a measure of stated son preference using NFHS questions about ideal number of children (Pande and Malhotra 2006; Gaudin 2011). Respondents were asked the ideal number of total children and the ideal number of boys and girls. We construct a dichotomous indicator of whether the respondent has an overall preference for sons (ideal number of boys is greater than ideal number of girls) or whether the respondent has no overall preference for sons (ideal number of boys is equal to or less than the ideal number of girls). This measure of stated son preference does not rely on explicitly asking respondents if they have preference for sons, and thus is less subject to reporting bias from women who may not want to openly state a preference for sons.

Stated son preference remains an important indicator of gender attitudes and underlying gender inequality in India (Gaudin 2011; Mitra 2014). However, there is debate in the literature about whether stated preferences correspond with actual behavior (Bongaarts 1994; Pritchett 1994). Past research indicates that stated son preferences from NFHS-1 match state-level sex ratios from the 1990 Indian census (Bhat, Mari, and Zavier 2003). However, stated son preferences have started to fall in recent history (Retherford and Roy 2003), while sex ratios remain skewed towards males (Jha et al. 2011).

This discrepancy between women's stated preferences and behavior does not mean that women are being dishonest about their true preferences. The combination of increasingly prevalent sex-selective abortion technologies and increasing resources of a rising middle class allows more Indian women to select out of having daughters, even though social norms concerning son preference are weakening (Kashyap and Villavicencio 2016; Jha et al. 2011; Arnold, Kishor, and Roy 2002; Retherford and Roy 2003). Thus, changes in stated son preferences might reflect the start of long-standing social processes that will eventually translate into declining sex ratios in India. For example, in South Korea sex ratios initially remained skewed even as stated son preference declined; however, by the early 1990s skewed sex ratios at birth had steadily declined and stated son preferences and sex ratios converged (Chung and Das Gupta 2007). Regardless, son preference cannot be equated with sex ratios, and they should be examined as separate but related social phenomena. We do not examine sex ratios in this paper because we focus on a sample of never pregnant women, for the reasons described above.

One limitation of our son preference measure is that we might underestimate son preference because respondents may report son preference only if they prefer an odd number of total children (e.g., one son; two sons and one daughter etc.). Although, in theory, respondents who prefer an even number of children may also report son 
preference (e.g., preferring two sons and zero daughters), descriptive evidence suggests that stated son preference is low among those who report desiring two children (Table 2, Panel B). As a robustness check we re-run models with several additional measures of stated son preference that consider the total number of desired children (discussed in the supplementary analysis section); the results are substantively the same.

Table 2: Type of employment and level of school, literacy, and desired family size (Panel A). Son preference, schooling, paid employment and desired family size (Panel B)

\begin{tabular}{|c|c|c|c|c|c|c|}
\hline Panel A & $\begin{array}{l}\text { No paid } \\
\text { employment } \\
\text { last } 12 \text { mo. }\end{array}$ & $\begin{array}{l}\text { Paid } \\
\text { employment } \\
\text { last } 12 \mathrm{mo} \text {. }\end{array}$ & $\begin{array}{l}\text { Paid } \\
\text { employment } \\
\text { agriculture } \\
\text { sector } \\
\text { last } 12 \mathrm{mo} \text {. }\end{array}$ & $\begin{array}{l}\text { Paid } \\
\text { employment } \\
\text { manufacturing } \\
\text { sector } \\
\text { last } 12 \mathrm{mo} .\end{array}$ & $\begin{array}{l}\text { Paid } \\
\text { employment } \\
\text { service sector } \\
\text { last } 12 \text { mo. }\end{array}$ & $\begin{array}{l}\text { Paid } \\
\text { employment } \\
\text { prof-tech sector } \\
\text { last } 12 \mathrm{mo} \text {. }\end{array}$ \\
\hline Median school level & 2.00 & 2.00 & 1.00 & 2.00 & 2.00 & 3.00 \\
\hline Mean years of schooling & 7.62 & 8.04 & 3.91 & 5.95 & 7.81 & 13.84 \\
\hline Mean literacy & 0.75 & 0.72 & 0.42 & 0.65 & 0.74 & 0.99 \\
\hline Desired family size & 2.04 & 1.97 & 2.22 & 2.08 & 2.00 & 1.78 \\
\hline $\mathrm{N}$ & 27,990 & 6,460 & 691 & 2,147 & 1,340 & 2,282 \\
\hline Panel B & $\begin{array}{l}\text { Desire } \\
1 \text { child }\end{array}$ & $\begin{array}{l}\text { Desire } \\
2 \text { children }\end{array}$ & $\begin{array}{l}\text { Desire } \\
3 \text { children }\end{array}$ & $\begin{array}{l}\text { Desire } 4 \text { or } \\
\text { more children }\end{array}$ & & \\
\hline Stated son preference & 0.14 & 0.02 & 0.70 & 0.12 & & \\
\hline Median school level & 2.00 & 2.00 & 2.00 & 2.00 & & \\
\hline Mean years of school & 10.58 & 8.59 & 6.06 & 5.78 & & \\
\hline Paid employment last 12 mo. & 0.21 & 0.19 & 0.15 & 0.16 & & \\
\hline $\mathrm{N}$ & 6,247 & 22,745 & 3,632 & 1,826 & & \\
\hline
\end{tabular}

\section{Results}

\subsection{Descriptive overview of women's participation in paid employment}

In total, $17 \%$ of our sample participated in full-time paid employment over the previous 12 months (Table 1). Distinguishing by sector, 3\% of the sample was in agricultural employment, $6 \%$ of the sample was in manufacturing employment, $3 \%$ of the sample was in service employment, and 5\% was in professional-technical employment (Table 1). These employment figures are considerably lower than comparable World Bank estimates for the same period due to the exclusion of unpaid, part-time, occasional, and seasonal labor (World Bank 2014). This is particularly the case for employment in agriculture, which is disproportionately seasonal, part-time, or unpaid.

Next, we look at how education and literacy (our indicators of skill) vary over the different categories of employment (Table 2). On average, there is not much difference 
in education and literacy between women who did not participate in full-time paid employment over the last 12 months $(n=27,990)$ and women who did $(n=6,460)$. The median schooling level of both groups of women was secondary school (level 2) and the average years of school was 8 for both groups (Table 2). Likewise, the respective percentage literate was $75 \%$ and $72 \%$ for women who did not and did participate in paid employment (Table 2).

When we disaggregate the employment variable by employment sector we find larger differences in education and literacy. For women employed in agriculture the median schooling level was primary school (level 1), for women employed in services and manufacturing it was secondary school (level 2), and for women employed in professional-technical jobs it was tertiary education (level 3) (Table 2). On average, women employed in agriculture had completed 4 years of school, women employed in manufacturing had completed 6 years of school, women employed in services had completed 8 years of school, and women employed in professional-technical had completed 14 years of school (Table 2). The percentage literate was $42 \%$ for women employed in agriculture, $65 \%$ for women employed in manufacturing, $74 \%$ for women employed in services, and $99 \%$ for women employed in professional-technical jobs (Table 2).

Thus, on average, compared to women who did not participate in paid employment, women employed in the agricultural sector were considerably less educated and literate; women employed in the manufacturing sector were somewhat less educated and literate; women employed in the service sector had similar levels of education and literacy; and women employed in the professional-technical sector were considerably more educated and literate.

\subsection{Logistic regression analysis of the relationship between women's paid employment and women's stated son preference using an aggregated measure of paid employment}

In our first set of models we use the aggregated measure of paid employment, which does not distinguish between employment sectors. We find there is no significant relationship between the stated son preference of women who had and who had not participated in full-time paid employment in the previous 12 months (Table 3, Column 1). 
Table 3: Paid employment and stated son preference including interactions with women's schooling and with women's literacy. Results presented as odds ratios

\begin{tabular}{|c|c|c|c|c|c|c|}
\hline & $\begin{array}{l}\text { (1) Stated son } \\
\text { preference }\end{array}$ & $\begin{array}{l}\text { (2) Stated son } \\
\text { preference }\end{array}$ & $\begin{array}{l}\text { (3) Stated son } \\
\text { preference }\end{array}$ & $\begin{array}{l}\text { (4) Stated son } \\
\text { preference }\end{array}$ & $\begin{array}{l}\text { (5) Stated son } \\
\text { preference }\end{array}$ & $\begin{array}{l}\text { (6) Stated son } \\
\text { preference }\end{array}$ \\
\hline \multirow[t]{2}{*}{ Paid employment } & 0.93 & $0.72^{\star \star}$ & $0.74^{* \star \star}$ & & & \\
\hline & $(0.05)$ & $(0.07)$ & $(0.07)$ & & & \\
\hline \multirow[t]{2}{*}{ Paid employment in agriculture } & & & & 0.96 & 0.85 & 0.86 \\
\hline & & & & $(0.11)$ & $(0.14)$ & $(0.12)$ \\
\hline \multirow[t]{2}{*}{ Paid employment in manufacturing } & & & & 0.90 & $0.71^{*}$ & $0.72^{* *}$ \\
\hline & & & & $(0.07)$ & $(0.10)$ & $(0.09)$ \\
\hline \multirow[t]{2}{*}{ Paid employment in services } & & & & 0.92 & $0.54^{*}$ & $0.64^{*}$ \\
\hline & & & & $(0.09)$ & $(0.13)$ & $(0.12)$ \\
\hline \multirow{2}{*}{$\begin{array}{l}\text { Paid employment in professional- } \\
\text { technical jobs }\end{array}$} & & & & 0.96 & 0.31 & 0.25 \\
\hline & & & & $(0.09)$ & $(0.33)$ & $(0.26)$ \\
\hline \multirow[t]{2}{*}{ Primary school } & $0.71^{\star \star \star}$ & $0.70^{\star \star *}$ & $0.71^{\star \star \star}$ & $0.71^{\star \star \star}$ & $0.70^{\star \star \star}$ & $0.71^{\star \star \star}$ \\
\hline & $(0.05)$ & $(0.05)$ & $(0.05)$ & $(0.05)$ & $(0.05)$ & $(0.05)$ \\
\hline \multirow[t]{2}{*}{ Secondary school } & $0.56^{\star \star \star}$ & $0.52^{\star \star \star}$ & $0.55^{\star \star \star}$ & $0.56^{\star \star \star}$ & $0.52^{\star \star \star}$ & $0.56^{* \star *}$ \\
\hline & $(0.06)$ & $(0.06)$ & $(0.06)$ & $(0.06)$ & $(0.05)$ & $(0.06)$ \\
\hline \multirow[t]{2}{*}{ Tertiary school } & $0.44^{\star \star *}$ & $0.38^{* * *}$ & $0.43^{\star * \star}$ & $0.44^{* * *}$ & $0.38^{* * *}$ & $0.43^{* * *}$ \\
\hline & $(0.05)$ & $(0.05)$ & $(0.05)$ & $(0.05)$ & $(0.05)$ & $(0.05)$ \\
\hline \multirow[t]{2}{*}{ Literate } & 0.88 & 0.88 & $0.83^{*}$ & 0.88 & 0.88 & $0.83^{*}$ \\
\hline & $(0.08)$ & $(0.08)$ & $(0.08)$ & $(0.08)$ & $(0.08)$ & $(0.08)$ \\
\hline \multirow[t]{2}{*}{ Paid employment * Primary } & & 1.04 & & & & \\
\hline & & $(0.17)$ & & & & \\
\hline \multirow[t]{2}{*}{ Paid employment * Secondary } & & $1.45^{\star *}$ & & & & \\
\hline & & $(0.18)$ & & & & \\
\hline \multirow[t]{2}{*}{ Paid employment * Tertiary } & & $1.69^{\star \star \star}$ & & & & \\
\hline & & $(0.27)$ & & & & \\
\hline \multirow[t]{2}{*}{ Paid employment * Literate } & & & $1.40^{* *}$ & & & \\
\hline & & & $(0.15)$ & & & \\
\hline \multirow{2}{*}{$\begin{array}{l}\text { Paid employment in agriculture * } \\
\text { Primary }\end{array}$} & & & & & 1.01 & \\
\hline & & & & & $(0.29)$ & \\
\hline \multirow{2}{*}{$\begin{array}{l}\text { Paid employment in agriculture * } \\
\text { Secondary }\end{array}$} & & & & & 1.45 & \\
\hline & & & & & $(0.37)$ & \\
\hline \multirow{2}{*}{$\begin{array}{l}\text { Paid employment in agriculture * } \\
\text { Tertiary }\end{array}$} & & & & & 1.00 & \\
\hline & & & & & $(0.00)$ & \\
\hline \multirow{2}{*}{$\begin{array}{l}\text { Paid employment in manufacturing * } \\
\text { Primary }\end{array}$} & & & & & 0.94 & \\
\hline & & & & & $(0.23)$ & \\
\hline \multirow{3}{*}{$\begin{array}{l}\text { Paid employment in manufacturing * } \\
\text { Secondary }\end{array}$} & & & & & $148^{*}$ & \\
\hline & & & & & 1.40 & \\
\hline & & & & & $(0.26)$ & \\
\hline
\end{tabular}


Behrman \& Duvisac: The relationship between women's paid employment and stated son preference in India

Table 3: (Continued)

\begin{tabular}{|c|c|c|c|c|c|c|}
\hline & $\begin{array}{l}\text { (1) Stated son } \\
\text { preference }\end{array}$ & $\begin{array}{l}\text { (2) Stated son } \\
\text { preference }\end{array}$ & $\begin{array}{l}\text { (3) Stated son } \\
\text { preference }\end{array}$ & $\begin{array}{l}\text { (4) Stated son } \\
\text { preference }\end{array}$ & $\begin{array}{l}\text { (5) Stated son } \\
\text { preference }\end{array}$ & $\begin{array}{l}\text { (6) Stated son } \\
\text { preference }\end{array}$ \\
\hline \multirow[t]{2}{*}{$\begin{array}{l}\text { Paid employment in manufacturing * } \\
\text { Tertiary }\end{array}$} & & & & & $2.41^{\text {** }}$ & \\
\hline & & & & & $(0.75)$ & \\
\hline \multirow{2}{*}{$\begin{array}{l}\text { Paid employment in services * } \\
\text { Primary }\end{array}$} & & & & & 1.41 & \\
\hline & & & & & $(0.49)$ & \\
\hline \multirow{2}{*}{$\begin{array}{l}\text { Paid employment in services * } \\
\text { Secondary }\end{array}$} & & & & & $1.95^{*}$ & \\
\hline & & & & & $(0.55)$ & \\
\hline \multirow{2}{*}{$\begin{array}{l}\text { Paid employment in services * } \\
\text { Tertiary }\end{array}$} & & & & & $2.75^{\star *}$ & \\
\hline & & & & & $(0.97)$ & \\
\hline \multirow{2}{*}{$\begin{array}{l}\text { Paid employment in prof-tech * } \\
\text { Primary }\end{array}$} & & & & & 1.83 & \\
\hline & & & & & $(2.74)$ & \\
\hline \multirow{2}{*}{$\begin{array}{l}\text { Paid employment in prof-tech * } \\
\text { Secondary }\end{array}$} & & & & & 3.01 & \\
\hline & & & & & & \\
\hline \multirow{2}{*}{$\begin{array}{l}\text { Paid employment in prof-tech * } \\
\text { Tertiary }\end{array}$} & & & & & 3.60 & \\
\hline & & & & & (3.85) & \\
\hline \multirow{2}{*}{$\begin{array}{l}\text { Paid employment in agriculture * } \\
\text { literate }\end{array}$} & & & & & & 1.28 \\
\hline & & & & & & $(0.29)$ \\
\hline \multirow{2}{*}{$\begin{array}{l}\text { Paid employment in manufacturing * } \\
\text { literate }\end{array}$} & & & & & & $1.45^{\star}$ \\
\hline & & & & & & $(0.22)$ \\
\hline \multirow{2}{*}{$\begin{array}{l}\text { Paid employment in services * } \\
\text { literate }\end{array}$} & & & & & & $1.69^{*}$ \\
\hline & & & & & & $(0.38)$ \\
\hline \multirow[t]{2}{*}{$\begin{array}{l}\text { Paid employment in prof-tech * } \\
\text { literate }\end{array}$} & & & & & & 3.94 \\
\hline & & & & & & $(4.12)$ \\
\hline Observations & 34,450 & 34,450 & 34,450 & 34,450 & $34,440^{\mathrm{a}}$ & 34,450 \\
\hline
\end{tabular}

Note: Robust standard errors clustered at the primary sampling unit level. Additional controls described in methods section and state fixed effects not shown.

*** $p<0.001,{ }^{* *} p<0.01,{ }^{*} p<0.05,+p<0.1$

(a) Agriculture*Tertiary perfectly predicts failure, thus this interaction is dropped and 10 observations were not used

On the other hand, women's education is significantly associated with reductions in women's stated son preference. Compared to women who did not attend school, women who attended primary school had a $29 \%$ reduction in the odds of stating a son preference; women who attended secondary school had a $44 \%$ reduction in the odds of stating a son preference, and women who attended tertiary school had a $56 \%$ reduction $(\mathrm{p}<0.001)$ (Table 3, Column 1). These results are consistent with the findings of Pande 
and Malhotra (2006) concerning the negative correlation between women's education and stated son preference.

In the next part of our analysis we include interactions between women's paid employment and education level to understand if the relationship between women's paid employment and stated son preference is different for women with higher levels of schooling (a proxy for skill). For women who never attended school, employment is associated with a $28 \%$ reduction in the odds of stating a son preference $(\mathrm{p}<0.01)$ (Table 3 , Column 2). For women who are not employed, primary, secondary, and tertiary school attainment is negatively associated with stating a son preference $(\mathrm{p}<0.01)$ (Table 3 , Column 2). However, there are significant positive interactions between women's paid employment and women's secondary attainment $(p<0.01)$ and between women's paid employment and women's tertiary attainment $(\mathrm{p}<0.001)$, which indicates that the negative relationship between women's paid employment and women's stated son preference diminishes at higher levels of school attainment (Table 3, Column 2).

To better contextualize these results, we graph the predicted probability of stated son preference by employment status at each of the four levels of schooling. For women with no formal schooling the predicted probability of stated son preference is $27 \%$ for non-employed women and $17 \%$ for employed women (Figure 1, top); for women with primary school level it is $18 \%$ for non-employed women and $11 \%$ for employed women (Figure 1, top); for women with secondary schooling it is $10 \%$ for non-employed women and $10 \%$ for employed women (Figure 1, top); for women with tertiary schooling it is 5\% for non-employed women and 7\% for employed women (Figure 1, top). Supplementary graphs with $95 \%$ confidence intervals show that differences in stated son preference by employment status are statistically significant for women with no school and primary schooling, but not for women with secondary or tertiary schooling (graphs available upon request).

Next, we conduct a multivariate analysis of the relationship between women's paid employment and stated son preference, including an interaction between paid employment and women's literacy to understand if the relationship between paid employment and stated son preference is different for women who are literate (a second proxy for skill). Paid employment is associated with a $26 \%$ reduction in the odds of stated son preference for women who are illiterate $(p<0.001)$ (Table 3, Column 3). Literacy is associated with a $17 \%$ reduction in the odds of stated son preference for women who are not employed $(\mathrm{p}<0.001)$ (Table 3, Column 3). However, there is a significant positive interaction between literacy and paid employment $(\mathrm{p}<0.01)$, which means that the negative relationship between paid employment and stated son preference diminishes for women who are literate (Table 3, Column 3). 
Figure 1: Predicted probabilities of women's stated son preference for women in paid employment and not in paid employment by different school level (top) and literacy (bottom)
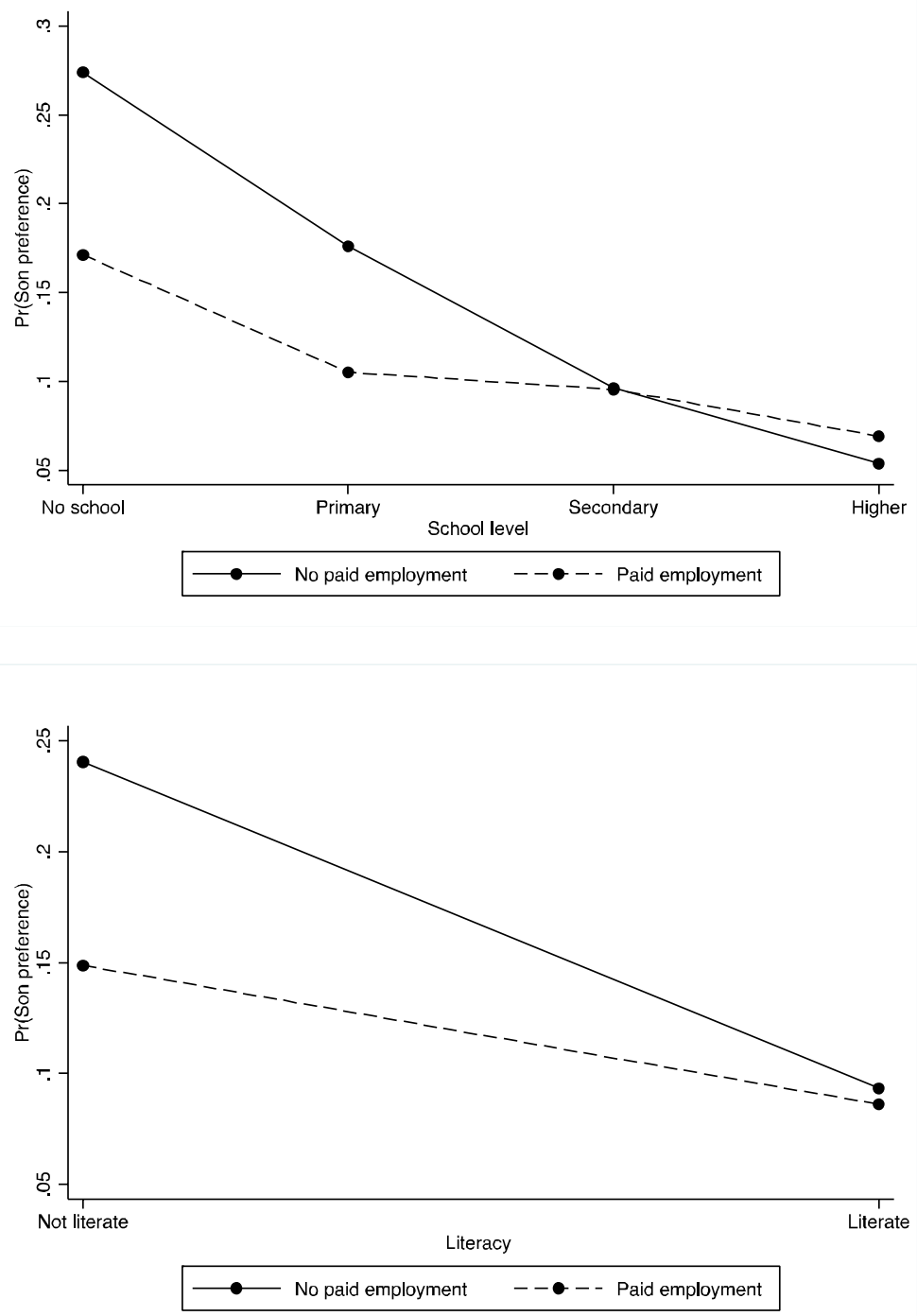
To contextualize these results, we graph the predicted probabilities of stated son preference by employment status and literacy. Among women who are illiterate the predicted probability of stated son preference is $24 \%$ for non-employed women and $15 \%$ for employed women (Figure 1, bottom). Among women who are literate the predicted probability of stated son preference is $9 \%$ for non-employed women and $9 \%$ for employed women (Figure 1, bottom). Supplementary graphs with 95\% confidence intervals show that differences in stated son preference by employment are statistically significant for women who are illiterate, but not for women who are literate (graphs available upon request).

Thus, our analysis suggests that paid employment is associated with a sizeable reduction in stated son preference for women with no or low levels of schooling, but no reduction for women with secondary or tertiary schooling levels. Likewise, paid employment is associated with a sizeable reduction in stated son preference for women who are illiterate, but with no reduction in stated son preference for women who are literate.

\subsection{Logistic regression analysis of the relationship between women's paid employment and women's stated son preference disaggregating by sector of employment}

In our next set of models we disaggregate paid employment by sector: agriculture, manufacturing, services, and professional-technical. In our models without interaction terms we find there is no significant relationship between employment in any of the four sectors and stated son preference compared to non-employed women (Table 3, Column 4).

In the next part of our analysis we include interactions between sector-specific paid employment variables and women's education. We find that full-time paid employment in the manufacturing sector in the previous 12 months is associated with a $29 \%$ reduction in the odds of stated son preference for women who never attended school $(\mathrm{p}<0.05)$ (Table 3, Column 5). Likewise, full-time paid employment in the service sector in the last 12 months is associated with a $46 \%$ reduction in the odds of stated son preference for women who never attended school $(p<0.05)$ (Table 3, Column 5). All three of the schooling level indicator variables (primary, secondary, tertiary) are negative and significant, which suggests increased schooling is negatively associated with stated son preference for women who are not employed (Table 3, Column 5). However, there are significant positive interactions between paid employment in the service and manufacturing sectors and the secondary and tertiary schooling variables, which indicates that the negative relationship between paid employment in the service 
and manufacturing sectors and stated son preference diminishes at higher levels of schooling (Table 3, Column 5).

Next, to better contextualize these results, we graph the predicted probability of stated son preference by paid employment in services, paid employment in manufacturing, and no paid employment, at each of the four levels of schooling. Among women who have no schooling the predicted probability of stated son preference is $27 \%$ for non-employed women, $18 \%$ for women employed in manufacturing, and 10\% for women employed in services (Figure 2, top). Among women with primary-level schooling the predicted probability of stated son preference is $18 \%$ for non-employed women, $10 \%$ for women employed in manufacturing, and $9 \%$ for women employed in services (Figure 2, top). Among women with secondary level schooling, the predicted probability of stated son preference is $10 \%$ for non-employed women, $10 \%$ for women employed in manufacturing, and 9\% for women employed in services (Figure 2, top). Among women with tertiary level schooling, the predicted probability of stated son preference is 5\% for non-employed women, $14 \%$ for women employed in manufacturing, and $8 \%$ for women employed in services (Figure 2, top).

Supplementary graphs with $95 \%$ confidence intervals show that differences in stated son preference by employment in the service/manufacturing sectors are statistically significant for women with no school and primary schooling, but not for women with secondary schooling (graphs available upon request). Women with tertiary-level schooling who are employed in manufacturing have significantly higher stated son preference than non-employed women. However, there is no significant difference in stated son preference between paid employment in services and no employment.

We also look at the interaction between paid employment in the four sectors and women's literacy, to understand if the relationship between paid employment and stated son preference is different for women who are literate (a second proxy for skill). For women who are illiterate, paid employment in manufacturing is associated with a $28 \%$ reduction in the odds of stated son preference $(\mathrm{p}<0.01)$ (Table 3 , Column 6), and paid employment in services is associated with a $36 \%$ reduction $(\mathrm{p}<0.05)$ (Table 3, Column $6)$. Literacy is associated with a $17 \%$ reduction in the odds of stated son preference for women who are not employed $(\mathrm{p}<0.05)$ (Table 3, Column 6). However, there are significant positive interactions between women's paid employment in the service and manufacturing sectors and literacy, which means that the negative relationship between women's paid employment in the service and manufacturing sectors and stated son preference goes away for women who are literate (Table 3, Column 6). 
Figure 2: Predicted probabilities of women's stated son preference for women in manufacturing and service sectors and women not in paid employment, by different school level (top) and literacy (bottom)
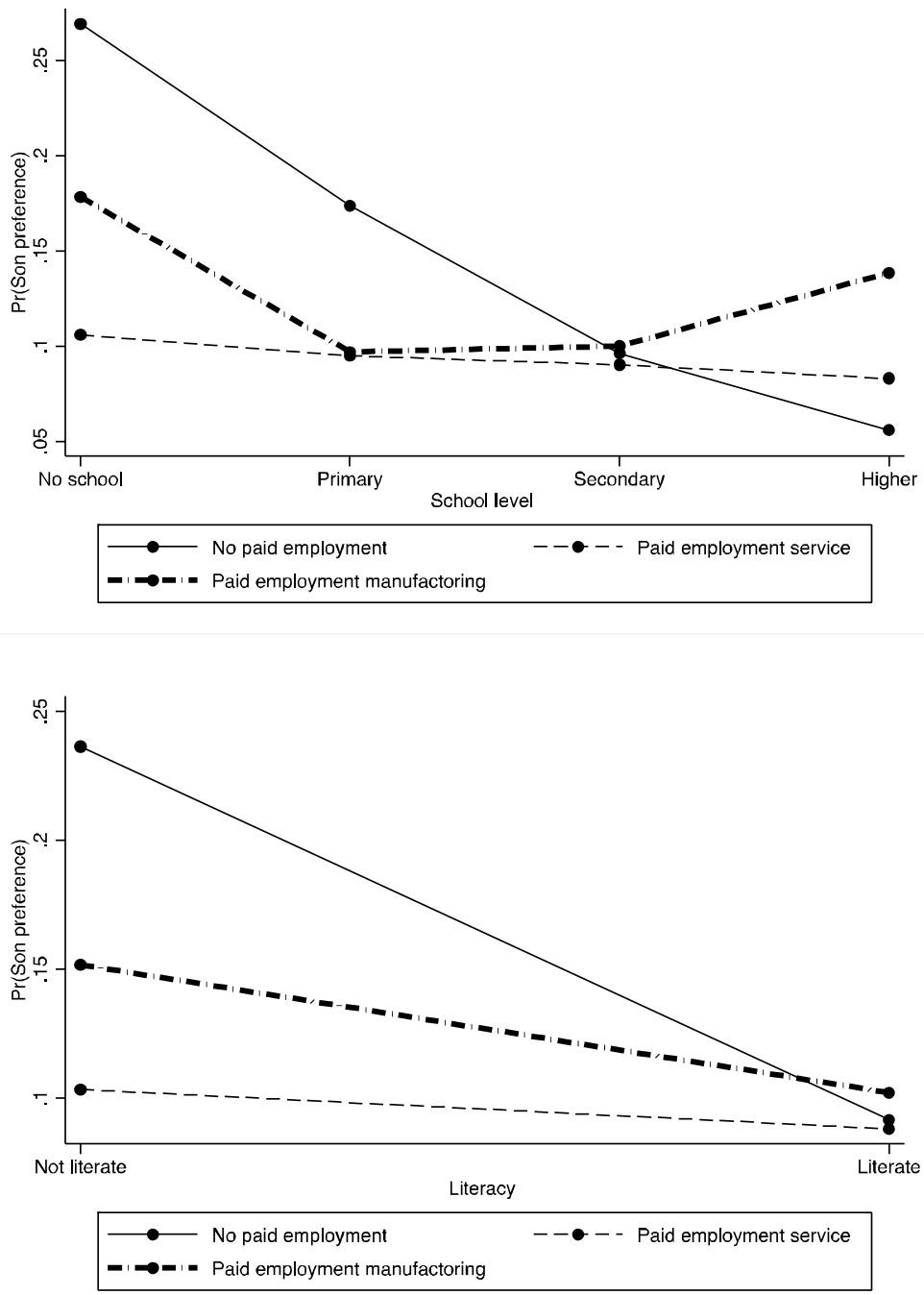
To contextualize these results, we graph the predicted probability of stated son preference for women who participated in paid employment in the manufacturing and service sectors for literate and illiterate women. Among illiterate women the predicted probability of stated son preference is $24 \%$ for women who are not employed, $15 \%$ for women employed in manufacturing, and 10\% for women employed in services (Figure 2 , bottom). Among literate women the predicted probability of stated son preference is $9 \%$ for women who are not employed, $12 \%$ for women employed in manufacturing, and $10 \%$ for women employed in services (Figure 2, bottom). Supplementary graphs with $95 \%$ confidence intervals show that differences in stated son preference by employment in service and manufacturing sectors are statistically significant for women who are illiterate, but not for women who are literate (graphs available upon request).

\subsection{Supplementary analyses}

To test the robustness of our results to a measure of son preference that considers the total number of desired children, we create an alternative measure of stated son preference where we subtract the ideal number of girls from the ideal number of boys and divide by the total desired number of children (Lai, Mu, and Ren 2014). This provides a continuous measure of stated son preference where values less than zero signal preference for daughters, values of zero signal no preference for either sex, and values greater than zero signal preference for sons. We recode this into a dichotomous indicator variable for preference for sons (the reference is no preference for sons). The results of a supplementary analysis with this alternative measure of son preference are identical to our main results (see Table A-3).

As an additional outcome, we also look at how many more boys than girls respondents prefer (zero, one, two etc.). Results are substantively the same as those presented in the analysis and are available upon request from the authors. We do not present these results because $90 \%$ of respondents who prefer sons prefer one more son than daughter; only $9 \%$ of respondents who prefer sons prefer two more sons than daughters, and $1 \%$ of respondents who prefer sons prefer three or more sons than daughters.

In addition, we re-run our main analyses including regional fixed effects and interactions between the categories of employment and region (Table A-4). Following Dyson and Moore (1983), we create three indicator variables to designate north, east, and south regions of India. Although these regional designations are very broad, they roughly categorize the different agricultural regimes described in Bardhan (1974, 1988), where the north of India is largely wheat-growing, more-intensive agriculture, and the south of India is rice-growing and allows for greater female participation in 
agricultural employment. Including these regional interactions allows us to test Bardhan's hypothesis linking differences in agricultural regime with differences in son preference. $^{8}$

Consistent with literature on regional differences in son preference, we find stated son preference is significantly lower in south and east India than in north India (Table A-4). Consistent with our main models, there is a significant negative association between women's paid employment and stated son preference (Table A-4). However, there is a significant positive interaction between women's participation in paid employment and stated son preference for both the south and east variables (Table A4). This indicates that the negative association between women's paid employment and stated son preference is smaller for women in the south and east of India than for women in the north of India.

However, when we disaggregate the employment measures by sector we find the interaction terms between regions and employment are significant only for services and the professional-technical sectors (Table A-4). Thus, our regional analysis provides limited support for Bardhan's hypothesis, since we find no significant differences in the agricultural variable by region. Our models indicate that the association between women's paid employment and stated son preference is largest in regions where stated son preference is highest (e.g., the north). This could be because women's paid employment has a larger negative association with stated son preference in contexts where women's employment leads to more dramatic shifts in women's traditional economic roles (i.e., in the north, where women have traditionally worked less).

\section{Discussion}

Our analysis explores the relationship between women's paid employment and women's stated son preference among a sample of Indian women who never had children. We find no significant association between women's paid employment and stated son preference when we use an aggregated measure of employment that does not distinguish between sectors. This finding is surprising, considering that past literature indicates a negative relationship between women's employment and female survival (an indicator of son preference) (Kishor 1993; Murthi, Guio, and Drèze 1995; Rosenzweig and Schultz 1982).

However, further analysis demonstrates that the relationship between women's paid employment and women's stated son preference varies depending on the sector

\footnotetext{
${ }^{8}$ We do not include regional fixed effects in our main set of models because state fixed effects control for geography at a lower level than region.
} 
and skill level of employment. For low-skilled women (e.g., women with a low level of education and women who were illiterate) there is a sizeable negative association between women's paid employment in the service and manufacturing sectors and women's stated son preference. However, this negative relationship went away for women at higher skill levels (e.g., women with secondary or tertiary education and women who were literate). In fact, employment in manufacturing is associated with significantly higher stated son preference for university-educated women than for women not in paid employment. Meanwhile, there were no significant associations between women's participation in paid agriculture or professional-technical employment and stated son preference.

We hypothesize that we found negative associations between women's paid employment and women's stated son preference for low-skilled women in the service and manufacturing sectors because these positions had the greatest potential to change the economic status of women within the family. Previous studies have found that many low-educated women in the service and manufacturing sectors are migrants to urban areas and are the first generation of women to make significant financial contributions to the economic well-being of their families (Neetha 2004; Sundari 2005). Furthermore, young female migrants are exposed to new social networks and increased social autonomy (Chakravarty and Chakravarty 2015; Neetha 2004), which might change women's preferences concerning their own offspring. While we were unable to formally test whether employment in services and manufacturing changes the 'economic value' of daughters, this is an important area for further quantitative and qualitative research.

On the other hand, the significantly higher levels of stated son preference of university-educated women employed in the manufacturing sector might indicate that employment provides middle class women with the resources to emulate the preferences and cultural practices of higher status/higher caste families. Alternatively, in higher socioeconomic status families the wage income of highly educated women might do little to change their economic status.

We hypothesize that we saw no association between women's paid employment in agricultural and the professional-technical sectors and stated son preference because women's employment in these sectors did not significantly transform the financial wellbeing of families. For example, agricultural workers' wages are often too low to dramatically change the economic status of their families, and thus employment in the agricultural sector may do little to alleviate the perception of women as an economic burden. Conversely, professional-technical workers often come from wealthier family backgrounds where women's income may not be crucial for financial well-being.

Interestingly, the negative association between women's paid employment and stated son preference is larger for women in north India (where son preference is 
stronger) than for women in south and east India. We hypothesize that this may be because women's employment in northern India represents a larger change in women's economic position in the household than in the south and east of India where traditionally women have participated in economic activities in the homestead at higher rates (Bardhan 1974, 1988).

Our analysis of the relationship between women's paid employment and women's stated son preference had several limitations. First, we cannot fully account for the possibility that the women who selected into employment were different from the women who did not. A second limitation is our lack of information about the duration of women's employment. In part this reflects the fact that good employment data is often collected separately from good demographic data. Our analysis highlights the necessity to bridge different disciplines in order to think about the relationship between employment and demographic processes. Finally, our analysis is limited to the relationship between women's own employment and women's stated son preference. Women's employment might affect the son preference of their families; however, we were unable to assess these questions using the NFHS sample.

Nonetheless, our analysis makes an important contribution to the literature on women's employment and son preference in India. By disaggregating the employment variable by sector, our analysis problematizes and refines the way previous studies (Kishor 1993; Murthi, Guio, and Drèze 1995; Rosenzweig and Schultz 1982) use women's employment as an indicator of empowerment. We show that not all forms of women's employment lead to women's empowerment or to a shift in women's social status. Future analyses should consider that women's employment can take many different forms and that the sector and skill levels of women's employment can be differentially associated with demographic outcomes.

It remains unclear what our findings mean for the future of son preference in India, given the slow growth in women's employment. Women's labor force participation peaked during the period studied (2005/2006) at $37 \%$, and subsequently declined to 27\% (World Bank 2016). Moreover, women's employment opportunities remain concentrated in the agricultural sector and these jobs are historically low paid and less secure. On the one hand, our analysis demonstrates the potential payoffs of providing stable and secure employment opportunities to the least-educated women in a country with large class-based inequalities in access to education and other resources. Yet it remains unlikely that women's employment will be the catalyst for large-scale reductions in son preference in the absence of stable and secure employment opportunities for marginalized women. 


\section{Acknowledgements}

We are grateful to Monica Caudillo, Abigail Weitzman, and Jere Behrman for helpful feedback on earlier versions of the manuscript. 


\section{References}

Abraham, V. (2009). Employment growth in rural India: Distress-driven? Economic and Political Weekly 44(16): 97-104.

Agarwal, B. (1988). Who sows? Who reaps? Women and land rights in India. The Journal of Peasant Studies 15(4): 531-581. doi:10.1080/03066158808438377.

Arnold, F., Choe, M.K., and Roy, T.K. (1998). Son preference, the family-building process and child mortality in India. Population Studies 52(3): 301-315. doi: $10.1080 / 0032472031000150486$.

Arnold, F., Kishor, S., and Roy, T.K. (2002). Sex-selective abortions in India. Population and Development Review 28(4): 759-785. doi:10.1111/j.1728-4457. 2002.00759.x.

Bardhan, P.K. (1974). On life and death questions. Economic and Political Weekly 9: 1293-1304.

Bardhan, P.K. (1988). Sex disparity in child survival in rural India. In: Srinivasan, T.N. and Bardhan, P.K. (eds.). Rural poverty in South Asia. New York: Columbia Press: 473-482.

Basu, A.M. (1999). Fertility decline and increasing gender imbalance including a possible South Indian turnaround. Development and Change 30(2): 237-263. doi:10.1111/1467-7660.00116.

Becker, G.S. (1981). Treatise on the family. Cambridge: Harvard University Press.

Bhat, P., Mari, N., and Zavier, A.J.F. (2003). Fertility decline and gender bias in northern India. Demography 40(2): 637-657. doi:10.2307/1515201.

Bharati, S., Shome, S., Pal, M., Chaudhury, P., and Bharati, P. (2011). Is son preference pervasive in India? Journal of Gender Studies 20(3): 291-298. doi:10.1080/ 09589236.2011.593328.

Bongaarts, J. (1994). The impact of population policies: Comment. Population and Development Review 20(3): 616-620. doi:10.2307/2137604.

Chakravarty, D. and Chakravarty, I. (2015). Women, labor, and the economy: From migrant menservants to uprooted girl children maids. New York: Routledge.

Chaudhary, R. and Verick, S. (2014). Female labor force participation in India and beyond. New Delhi: International Labour Organization (ILO Asia-Pacific Working Paper October 2014). 
Chung, W. and Das Gupta, M. (2007). The decline of son preference in South Korea: The roles of development and public policy. Population and Development Review 33(4): 757-783. doi:10.1111/j.1728-4457.2007.00196.x.

Das Gupta, M., Zhenghua, J., Bohua, L., Zhenming, X., Chung, W., and Hwa-Ok, B. (2003). Why is son preference so persistent in East and South Asia? A crosscountry study of China, India and the Republic of Korea. The Journal of Development Studies 40(2): 153-187. doi:10.1596/1813-9450-2942.

Diamond-Smith, N., Luke, N., and McGarvey, S. (2008). Too many girls, too much dowry: Son preference and daughter aversion in rural Tamil Nadu, India. Culture, Health \& Sexuality 10(7): 697-708. doi:10.1080/13691050802061665.

Dyson, T. and Moore, M. (1983). On kinship structure, female autonomy, and demographic behavior in India. Population and Development Review 9(1): 3560. doi:10.2307/1972894.

Ferrant, G., Pesando, L.M., and Nowacka, K. (2014). Unpaid care work: The missing link in the analysis of gender gaps in labor outcomes. Geneva: OECD Development Center (Issues Paper October 2014).

Gaudin, S. (2011). Son preference in Indian families: Absolute versus relative wealth effects. Demography 48(1): 343-370. doi:10.1007/s13524-010-0006-z.

Jensen, R. (2012). Do labor market opportunities affect young women's work and family decisions? Experimental evidence from India. The Quarterly Journal of Economics 127: 753-792. doi:10.1093/qje/qjs002.

Jha, P., Kesler, M.A., Kumar, R., Ram, F., Ram, U., Aleksandrowicz, L., Bassani, D.G., Chandra, S., and Banthia, J.K. (2011). Trends in selective abortions of girls in India: Analysis of nationally representative birth histories from 1990 to 2005 and census data from 1991 to 2011. The Lancet 377(9781): 1921-1928. doi:10.1016/ S0140-6736(11)60649-1.

Kasarda, J.D. (1971). Economic structure and fertility: A comparative analysis. Demography 8(3): 3017-3317. doi:10.2307/2060619.

Kashyap, R. and Villavicencio, F. (2016). The dynamics of son preference, technology diffusion, and fertility decline underlying distorted sex ratios at birth: A simulation approach. Demography 53(5): 1261-1281. doi:10.1007/s13524-0160500-z.

Kishor, S. (1993). May God give sons to all: Gender and child mortality in India. American Sociological Review 58(2): 247-265. doi:10.2307/2095969. 
Lai, Q., Mu, Z., and Ren, Q. (2014). Regional influences on Chinese women's fertility desires: Development and patriarchal culture [unpublished manuscript]. Princeton: Princeton University.

Mitra, A. (2014). Son preference in India: Implications for gender development. Journal of Economic Issues 48(4): 1021-1037.

Mitra, A. (2005). Women in the urban informal sector: Perpetuation of meagre earnings. Development and Change 36(2): 291-316. doi:10.1111/j.0012-155X. 2005.00412.x.

Mitra, S. (2006). Patterns of female employment in urban India: Analysis of NSS data (1983 to 1999-2000). Economic and Political Weekly 41(48): 5000-5008.

Mitra, A. and Singh, P. (2006). Human capital attainment and female labor force participation - The Kerala Puzzle. Journal of Economic Issues 40(3): 779-798. doi:10.1080/00213624.2006.11506945.

Mukund, K. (1999). Women's property rights in South India: A review. Economic and Political Weekly 34(22): 1352-1358.

Murthi, M., Guio, A.C., and Drèze, J. (1995). Mortality, fertility and gender bias in India. London: London School of Economics and Political Science (Discussion paper No. 61, Development Economics Research Programme, STICERD).

Neetha, N. (2004). Making of female breadwinners: Migration and social networking of women domestics in Delhi. Economic and Political Weekly 39(17): 1681-1688.

Noponen, H. (1991). The dynamics of work and survival for the urban poor: A gender analysis of panel data from Madras. Development and Change 22: 233-260. doi:10.1111/j.1467-7660.1991.tb00410.x.

Panda, P.K. (2003). Poverty and young women's employment: Linkages in Kerala. Economic and Political Weekly 38(38): 4034-4042.

Pande, R. and Astone, N.M. (2007). Explaining son preference in rural India: The independent role of structural versus individual factors. Population Research and Policy Review 26(2): 1-29. doi:10.1007/s11113-006-9017-2.

Pande, R. and Malhotra, A. (2006). Son preference and daughter neglect in India: What happens to living girls? Washington, D.C.: International Center for Research on Women.

Pritchett, L.H. (1994). Desired fertility and the impact of population policies. Population and Development Review 20(1): 1-55. doi:10.2307/2137629. 
Retherford, R.D. and Roy, T.K. (2003). Factors affecting sex-selective abortion in India and 17 major states. Mumbai: International Institute for Population Sciences (National Family Health Survey Subject Reports No. 21).

Robitaille, M. (2013). Determinants of stated son preference in India: Are men and women different? The Journal of Development Studies 49(5): 657-669. doi:10.1080/00220388.2012.682986.

Rosenzweig, M. and Schultz, T.P. (1982). Market opportunities, genetic endowments and the intrafamily distribution of resources: Child survival in rural India. American Economic Review 72(4): 803-815.

Rustagi, P. (2010). Employment trends for women in India. New Delhi: International Labor Organization (ILO Asia-Pacific Working Paper June 2010).

Saradamoni, K. (1994). Women, Kerala, and some development issues. Economic and Political Weekly 29(9): 501-509.

Schockaert, I. (2005). Women's employment and fertility in Latin America: A review of the question. Population 60(1-2): 149-168. doi:10.3917/pope.501.0149.

Sen, A. and Sengupta, S. (1983). Malnutrition of rural children and the sex bias. Economic and Political Weekly 18(19/21): 855-864.

Singh, P. and Pandey, A. (2005). Women in call centers. Economic and Weekly 40(7): 684-688.

Srinivasan, P. and Lee, G.R. (2004). The dowry system in northern India: Women's attitudes and social change. Journal of Marriage and Family 66(5): 1108-1117. doi:10.1111/j.0022-2445.2004.00081.x.

Sudha, S. and Rajan, S.I. (1999). Female demographic disadvantage in India 19811991: Sex selective abortion and female infanticide. Development and Change 30(3): 585-618. doi:10.1111/1467-7660.00130.

Sundari, S. (2005). Migration as a livelihood strategy: A gender perspective. Economic and Political Weekly 40(22/23): 2295-2303.

Woetzel, J., Madgavkar, A., Ellingrud, K., Labaye, E., Devillard, S., Kutcher, E., Manyika, J., Dobbs, R., and Krishnan, M. (2015). The power of parity: How advancing women's equality can add $\$ 12$ trillion to global growth. New York: McKinsey Global Institute.

World Bank (2014). India: Women, work, and employment. Washington, D.C.: World Bank. 
World Bank (2016). Labor force participation rate, female (\% of female population ages $15+$ ) (modeled ILO estimate) [electronic resource]. Washington, D.C.: World Bank. http://data.worldbank.org/indicator/SL.TLF.CACT.FE.ZS 
Behrman \& Duvisac: The relationship between women's paid employment and stated son preference in India

\section{Appendix}

\section{Table A-1: Categorization of employment by sector ${ }^{9}$}

\begin{tabular}{|c|c|c|c|}
\hline Professional & Services & Manufacturing & $\begin{array}{l}\text { Agriculture, Fishing, } \\
\text { Mining, Forestry }\end{array}$ \\
\hline Physical Scientists & Stenographers, Typists & Manufacturers, Agents & $\begin{array}{l}\text { Farm plantation, dairy and } \\
\text { other managers }\end{array}$ \\
\hline $\begin{array}{l}\text { Architects, Engineers, } \\
\text { Technologists }\end{array}$ & $\begin{array}{l}\text { Book keepers, Cashiers and } \\
\text { related workers }\end{array}$ & Metal processors & Cultivators \\
\hline Engineering technicians & Transport conductors and Guards & $\begin{array}{l}\text { Wood preparation workers and } \\
\text { paper makers }\end{array}$ & $\begin{array}{l}\text { Farmers other than } \\
\text { cultivators }\end{array}$ \\
\hline Aircraft and Ship Officers & $\begin{array}{l}\text { Mail Distributors and related } \\
\text { workers }\end{array}$ & $\begin{array}{l}\text { Chemical processors and related } \\
\text { workers }\end{array}$ & Agricultural laborers \\
\hline Life Scientists & $\begin{array}{l}\text { Telephone and Telegraph } \\
\text { operators }\end{array}$ & $\begin{array}{l}\text { Spinners, weavers, knitters, } \\
\text { dyers }\end{array}$ & $\begin{array}{l}\text { Plantation laborers and } \\
\text { related worker }\end{array}$ \\
\hline Life science technicians & $\begin{array}{l}\text { Merchants and Shopkeepers, } \\
\text { Wholesale traders }\end{array}$ & $\begin{array}{l}\text { Tanners, fellmonger and pelt } \\
\text { dressers }\end{array}$ & Other farm workers \\
\hline Physicians and Surgeons & $\begin{array}{l}\text { Technical salesmen and } \\
\text { Commercial travelers }\end{array}$ & Food and beverage processors & Forestry workers \\
\hline $\begin{array}{l}\text { Nursing and other Medical and } \\
\text { Health technicians }\end{array}$ & $\begin{array}{l}\text { Salesmen, Shop Assistants and } \\
\text { related workers }\end{array}$ & $\begin{array}{l}\text { Tobacco prepares and tobacco } \\
\text { product makers }\end{array}$ & $\begin{array}{l}\text { Hunters and related } \\
\text { workers }\end{array}$ \\
\hline $\begin{array}{l}\text { Scientific, medical and technical } \\
\text { persons }\end{array}$ & $\begin{array}{l}\text { Insurance, Real Estate, } \\
\text { Securities workers }\end{array}$ & $\begin{array}{l}\text { Tailors, dress makers, sewers, } \\
\text { upholstery }\end{array}$ & $\begin{array}{l}\text { Fishermen and related } \\
\text { workers }\end{array}$ \\
\hline Mathematicians and Statisticians & $\begin{array}{l}\text { Money lenders and Pawn } \\
\text { brokers }\end{array}$ & $\begin{array}{l}\text { Shoemakers and leather good } \\
\text { makers }\end{array}$ & $\begin{array}{l}\text { Miners, quarrymen, well } \\
\text { drillers and related workers }\end{array}$ \\
\hline Economists and related workers & Sales workers & $\begin{array}{l}\text { Carpenters, cabinet and related } \\
\text { workers }\end{array}$ & Stone cutter and carvers \\
\hline $\begin{array}{l}\text { Accountants, auditors and } \\
\text { related workers }\end{array}$ & Hotel and restaurant keepers & Machinery fitters, assemblers & Blacksmiths, tool makers \\
\hline $\begin{array}{l}\text { Social Scientists and related } \\
\text { workers }\end{array}$ & $\begin{array}{l}\text { House keepers, matrons and } \\
\text { stewards }\end{array}$ & $\begin{array}{l}\text { Plumbers, welders, sheet metal } \\
\text { workers }\end{array}$ & Laborers \\
\hline Jurists & $\begin{array}{l}\text { Cooks, waiters, bartenders and } \\
\text { related workers }\end{array}$ & $\begin{array}{l}\text { Jewelry and precious metal } \\
\text { workers }\end{array}$ & \\
\hline Teachers & $\begin{array}{l}\text { Maids and other house keeping } \\
\text { service workers }\end{array}$ & $\begin{array}{l}\text { Glass formers, potters and } \\
\text { related workers }\end{array}$ & \\
\hline $\begin{array}{l}\text { Poets, Authors, Journalists and } \\
\text { related workers }\end{array}$ & $\begin{array}{l}\text { Building caretakers, sweepers, } \\
\text { cleaners }\end{array}$ & $\begin{array}{l}\text { Rubber and plastic products } \\
\text { makers }\end{array}$ & \\
\hline $\begin{array}{l}\text { Sculptors, Painters, } \\
\text { Photographers }\end{array}$ & $\begin{array}{l}\text { Launderers, dry- cleaners and } \\
\text { pressers }\end{array}$ & $\begin{array}{l}\text { Paper products makers, printing } \\
\text { and related workers }\end{array}$ & \\
\hline $\begin{array}{l}\text { Composers and Performing } \\
\text { Artists }\end{array}$ & $\begin{array}{l}\text { Hair dresser, barbers, } \\
\text { beauticians }\end{array}$ & Painters and production workers & \\
\hline Professional Workers & Protective service workers & $\begin{array}{l}\text { Stationery engines and related } \\
\text { equipment }\end{array}$ & \\
\hline Elected and Legislative Officials & Service workers & Transport equipment operators & \\
\hline Administrators and Government & & Electrical fitters and related & \\
\hline Officials & & electrical workers & \\
\hline Proprietors, Directors and & & Broadcasting and sound & \\
\hline Managers & & equipment operators & \\
\hline
\end{tabular}

${ }^{9}$ In constructing the employment sectors - agriculture, manufacturing, service and professional-technical we tried to maintain the broad categories of economy activity, as well as the broad categories employed by the NFHS. The NFHS provides detailed occupational titles, which were then categorized by employment sector based on the occupation title. 
Table A-2: Logistic regression analysis of the relationship between paid employment and stated son preference including interactions with women's schooling using continuous specification of school. Results presented as odds ratios

\begin{tabular}{|c|c|c|}
\hline & (1) Stated son preference & (2) Stated son preference \\
\hline \multirow[t]{2}{*}{ Paid employment } & $0.72^{\star \star \star}$ & \\
\hline & $(0.06)$ & \\
\hline \multirow[t]{2}{*}{ Paid employment in agriculture } & & 0.86 \\
\hline & & $(0.13)$ \\
\hline \multirow[t]{2}{*}{ Paid employment in manufacturing } & & $0.65^{\star * *}$ \\
\hline & & $(0.08)$ \\
\hline \multirow[t]{2}{*}{ Paid employment in services } & & $0.56^{\star \star}$ \\
\hline & & $(0.10)$ \\
\hline \multirow{2}{*}{ Paid employment in professional-technical jobs } & & 0.86 \\
\hline & & $(0.31)$ \\
\hline \multirow[t]{2}{*}{ Years of school } & $0.93^{* * *}$ & $0.94^{\star * *}$ \\
\hline & $(0.01)$ & $(0.01)$ \\
\hline \multirow[t]{2}{*}{ Paid employment * years of school } & $1.04^{* * *}$ & \\
\hline & $(0.01)$ & \\
\hline \multirow[t]{2}{*}{ Paid employment in agriculture * years of school } & & 1.03 \\
\hline & & $(0.03)$ \\
\hline \multirow[t]{2}{*}{ Paid employment in manufacturing * years of school } & & $1.05^{\star \star}$ \\
\hline & & $(0.02)$ \\
\hline \multirow[t]{2}{*}{ Paid employment in services * years of school } & & $1.07^{* * *}$ \\
\hline & & $(0.02)$ \\
\hline \multirow[t]{2}{*}{ Paid employment in prof-tech * years of school } & & 1.02 \\
\hline & & $(0.03)$ \\
\hline Observations & 34,450 & 34,450 \\
\hline
\end{tabular}

Note: Robust standard errors clustered at the primary sampling unit level. Additional controls described in methods section and state fixed effects not shown.

${ }^{* * *} p<0.001,{ }^{* *} p<0.01,{ }^{*} p<0.05,+p<0.1$ 
Behrman \& Duvisac: The relationship between women's paid employment and stated son preference in India

Table A-3: Logistic regression analysis of the relationship between paid employment and stated son preference (alternative measure) including interactions with women's schooling and with women's literacy. Results presented as odds ratios

\begin{tabular}{|c|c|c|c|c|}
\hline & $\begin{array}{l}\text { (1) Alternative } \\
\text { measure of stated } \\
\text { son preference }\end{array}$ & $\begin{array}{l}\text { (2) Alternative } \\
\text { measure of stated } \\
\text { son preference }\end{array}$ & $\begin{array}{l}\text { (3) Alternative } \\
\text { measure of stated } \\
\text { son preference }\end{array}$ & $\begin{array}{l}\text { (4) Alternative } \\
\text { measure of stated } \\
\text { son preference }\end{array}$ \\
\hline \multirow[t]{2}{*}{ Paid employment } & $0.72^{* *}$ & $0.74^{\star \star \star}$ & & \\
\hline & $(0.07)$ & $(0.07)$ & & \\
\hline \multirow[t]{2}{*}{ Paid employment in agriculture } & & & 0.85 & 0.86 \\
\hline & & & $(0.14)$ & $(0.12)$ \\
\hline \multirow[t]{2}{*}{ Paid employment in manufacturing } & & & $0.71^{*}$ & $0.72^{* *}$ \\
\hline & & & $(0.10)$ & $(0.09)$ \\
\hline \multirow[t]{2}{*}{ Paid employment in services } & & & $0.54^{*}$ & $0.64^{*}$ \\
\hline & & & $(0.13)$ & $(0.12)$ \\
\hline \multirow[t]{2}{*}{ Paid employment in professional-technical jobs } & & & 0.31 & 0.25 \\
\hline & & & $(0.33)$ & $(0.26)$ \\
\hline \multirow[t]{2}{*}{ Primary school } & $0.70^{\star \star *}$ & $0.71^{* * *}$ & $0.70^{* * *}$ & $0.71^{\star \star *}$ \\
\hline & $(0.05)$ & $(0.05)$ & $(0.05)$ & $(0.05)$ \\
\hline \multirow[t]{2}{*}{ Secondary school } & $0.52^{\star \star \star}$ & $0.55^{\star \star \star}$ & $0.52^{* \star \star}$ & $0.56^{\star \star *}$ \\
\hline & $(0.06)$ & $(0.06)$ & $(0.05)$ & $(0.06)$ \\
\hline \multirow[t]{2}{*}{ Tertiary school } & $0.38^{\star \star *}$ & $0.43^{\star \star \star}$ & $0.38^{* \star *}$ & $0.43^{* * *}$ \\
\hline & $(0.05)$ & $(0.05)$ & $(0.05)$ & $(0.05)$ \\
\hline \multirow[t]{2}{*}{ Literate } & 0.88 & $0.83^{*}$ & 0.88 & $0.83^{*}$ \\
\hline & $(0.08)$ & $(0.08)$ & $(0.08)$ & $(0.08)$ \\
\hline \multirow[t]{2}{*}{ Paid employment * Primary } & 1.04 & & & \\
\hline & $(0.17)$ & & & \\
\hline \multirow[t]{2}{*}{ Paid employment * Secondary } & $1.45^{\star \star}$ & & & \\
\hline & $(0.18)$ & & & \\
\hline \multirow[t]{2}{*}{ Paid employment * Tertiary } & $1.69^{\star \star \star}$ & & & \\
\hline & $(0.27)$ & & & \\
\hline \multirow[t]{2}{*}{ Paid employment * Literate } & & $1.40^{* *}$ & & \\
\hline & & $(0.15)$ & & \\
\hline \multirow[t]{2}{*}{ Paid employment in agriculture * Primary } & & & 1.01 & \\
\hline & & & $(0.29)$ & \\
\hline \multirow[t]{2}{*}{ Paid employment in agriculture * Secondary } & & & 1.45 & \\
\hline & & & $(0.37)$ & \\
\hline
\end{tabular}


Table A-3: (Continued)

\begin{tabular}{|c|c|c|c|c|}
\hline & $\begin{array}{l}\text { (1) Alternative } \\
\text { measure of stated } \\
\text { son preference }\end{array}$ & $\begin{array}{l}\text { (2) Alternative } \\
\text { measure of stated } \\
\text { son preference }\end{array}$ & $\begin{array}{l}\text { (3) Alternative } \\
\text { measure of stated } \\
\text { son preference }\end{array}$ & $\begin{array}{l}\text { (4) Alternative } \\
\text { measure of stated } \\
\text { son preference }\end{array}$ \\
\hline \multirow[t]{2}{*}{ Paid employment in agriculture * Tertiary } & & & 1.00 & \\
\hline & & & $(0.00)$ & \\
\hline \multirow[t]{2}{*}{ Paid employment in manufacturing * Primary } & & & 0.94 & \\
\hline & & & $(0.23)$ & \\
\hline \multirow{2}{*}{$\begin{array}{l}\text { Paid employment in manufacturing * } \\
\text { Secondary }\end{array}$} & & & $1.48^{*}$ & \\
\hline & & & $(0.26)$ & \\
\hline \multirow[t]{2}{*}{ Paid employment in manufacturing * Tertiary } & & & $2.41^{* *}$ & \\
\hline & & & $(0.75)$ & \\
\hline \multirow[t]{2}{*}{ Paid employment in services * Primary } & & & 1.41 & \\
\hline & & & $(0.49)$ & \\
\hline \multirow[t]{2}{*}{ Paid employment in services * Secondary } & & & $1.95^{*}$ & \\
\hline & & & $(0.55)$ & \\
\hline \multirow[t]{2}{*}{ Paid employment in services * Tertiary } & & & $2.75^{\star \star}$ & \\
\hline & & & $(0.97)$ & \\
\hline \multirow[t]{2}{*}{ Paid employment in prof-tech * Primary } & & & 1.83 & \\
\hline & & & $(2.74)$ & \\
\hline \multirow[t]{2}{*}{ Paid employment in prof-tech * Secondary } & & & 3.01 & \\
\hline & & & $(3.22)$ & \\
\hline \multirow[t]{2}{*}{ Paid employment in prof-tech * Tertiary } & & & 3.60 & \\
\hline & & & $(3.85)$ & \\
\hline \multirow[t]{2}{*}{ Paid employment in agriculture * literate } & & & & 1.28 \\
\hline & & & & $(0.29)$ \\
\hline \multirow[t]{2}{*}{ Paid employment in manufacturing * literate } & & & & $1.45^{\star}$ \\
\hline & & & & $(0.22)$ \\
\hline \multirow[t]{2}{*}{ Paid employment in services * literate } & & & & $1.69^{*}$ \\
\hline & & & & $(0.38)$ \\
\hline \multirow[t]{2}{*}{ Paid employment in prof-tech * literate } & & & & 3.94 \\
\hline & & & & $(4.12)$ \\
\hline Observations & 34,450 & 34,450 & 34,450 & 34,450 \\
\hline
\end{tabular}

Note: Robust standard errors clustered at the primary sampling unit level. Additional controls described in methods section and state fixed effects not shown.

${ }^{\star * *} p<0.001,{ }^{* *} p<0.01,{ }^{*} p<0.05,+p<0.1$

(a) Agriculture* Tertiary perfectly predicts failure, thus this interaction is dropped and 10 observations were not used 
Behrman \& Duvisac: The relationship between women's paid employment and stated son preference in India

\section{Table A-4: Logistic regression analysis of the relationship between paid employment and stated son preference including interactions with region. Results presented as odds ratios}

\begin{tabular}{|c|c|c|}
\hline & (1) Stated son preference & (2) Stated son preference \\
\hline \multirow[t]{2}{*}{ Paid employment last 12 mo. } & $0.67^{* \star *}$ & \\
\hline & $(0.06)$ & \\
\hline \multirow[t]{2}{*}{ Paid employment in agriculture } & & 0.86 \\
\hline & & $(0.17)$ \\
\hline \multirow[t]{2}{*}{ Paid employment in manufacturing } & & $0.79+$ \\
\hline & & $(0.10)$ \\
\hline \multirow[t]{2}{*}{ Paid employment in services } & & $0.49^{\star *}$ \\
\hline & & $(0.13)$ \\
\hline \multirow[t]{2}{*}{ Paid employment in prof-tech jobs } & & $0.41^{* * *}$ \\
\hline & & $(0.10)$ \\
\hline \multirow[t]{2}{*}{ East (ref North) } & $0.47^{* \star *}$ & $0.46^{\star \star *}$ \\
\hline & $(0.07)$ & $(0.07)$ \\
\hline \multirow[t]{2}{*}{ South (ref North) } & $0.21^{\star \star \star}$ & $0.21^{\star \star *}$ \\
\hline & $(0.04)$ & $(0.04)$ \\
\hline \multirow[t]{2}{*}{ Paid employmentEast } & $1.63^{\star \star *}$ & \\
\hline & $(0.19)$ & \\
\hline \multirow[t]{2}{*}{ Paid employment ${ }^{\star}$ South } & $1.58^{\star *}$ & \\
\hline & $(0.23)$ & \\
\hline \multirow[t]{2}{*}{ Paid employment in agriculture*East } & & 1.24 \\
\hline & & $(0.32)$ \\
\hline \multirow[t]{2}{*}{ Paid employment in agriculture*South } & & 1.11 \\
\hline & & $(0.32)$ \\
\hline \multirow[t]{2}{*}{ Paid employment in manufacturing ${ }^{\star}$ East } & & $1.33+$ \\
\hline & & $(0.22)$ \\
\hline \multirow[t]{2}{*}{ Paid employment in manufacturing*South } & & 1.06 \\
\hline & & $(0.25)$ \\
\hline \multirow[t]{2}{*}{ Paid employment in services ${ }^{*}$ East } & & $2.04^{*}$ \\
\hline & & $(0.60)$ \\
\hline \multirow[t]{2}{*}{ Paid employment in services ${ }^{*}$ South } & & $2.62^{\star *}$ \\
\hline & & $(0.86)$ \\
\hline \multirow[t]{2}{*}{ Paid employment in prof-techEast } & & $2.93^{\star \star *}$ \\
\hline & & $(0.75)$ \\
\hline \multirow[t]{2}{*}{ Paid employment in prof-tech ${ }^{*}$ South } & & $3.04^{* \star *}$ \\
\hline & & $(0.91)$ \\
\hline \multirow[t]{2}{*}{ Constant } & $0.48^{\star \star *}$ & $0.48^{\star \star *}$ \\
\hline & $(0.10)$ & $(0.10)$ \\
\hline Observations & 34,450 & 34,450 \\
\hline
\end{tabular}

Note: Robust standard errors clustered at the primary sampling unit level. Additional controls described in methods section and state fixed effects not shown.

${ }^{* * *} p<0.001,{ }^{* *} p<0.01,{ }^{*} p<0.05,+p<0.1$ 